Forthcoming: 2(1) Trade L. \& Dev. 1 (2010).

\title{
FIVE JUSTIFICATIONS FOR INVESTMENT TREATIES: A CRITICAL DISCUSSION
}

\author{
GUS VAN HARTEN*
}

The article examines five common justifications for the investment treaty system in order to bighlight aspects of the system that give cause for concern. First, it examines whether investment treaties are a means to encourage foreign direct investment and concludes that this expectation is contradicted by common provisions in investment treaties and is unsupported by the preponderance of empirical evidence. If this justification was a factor in the decisions of states to conclude investment treaties - or of international organizations to promote them - then these decisions appear to have been based on incomplete knowledge and analysis of the anticipated benefits. Second, the article examines the claim that investment treaties respond to the bias and unreliability of domestic courts and criticizes investment treaties in this respect for being both under-inclusive (by extending access to international adjudication to a narrow class of private actors only) and over-inclusive (by failing to account for situations where domestic courts offer justice to a foreign investor). Third, the paper examines the claim that investment treaty arbitration advances the rule of law in the resolution of investorstate disputes and questions this claim after considering how investment treaty arbitration fails to incorporate key institutional safeguards of judicial independence that are present in other adjudicative systems that resolve public law claims. Fourth, the paper examines the argument that investment treaties affirm the sovereignty and bargaining strategies of states and outlines tentative evidence that governments did not test carefully the anticipated benefits of the treaties, did not appreciate fully the risks of investor-state arbitration, and did not carry out sophisticated cost-benefit analyses prior to committing themselves to the investment treaty system. Finally, the paper examines the justification that investment treaties were endorsed by the democratic processes of states and draws attention both to the role of arbitrators in giving meaning to the treaties and to certain aspects of investment treaties that appear to undermine democratic choice. Based on this analysis, it is recommended that governments exercise greater care when considering entry into the system or, more likely, the maintenance or renewal of existing treaties, and that governments consider options for reform.

\section{TABLE OF CONTENTS}

I. INTRODUCTION

II. PRESSURE FOR REFORM

III. FOCUS ON "MUSCULAR" InVESTMENT TREATIES

IV. Discussion

A. Justification 1: Investment Treaties are a means to encourage Foreign Investment

B. Justification 2: Investment Treaties respond to the Bias and Unreliability of Domestic Courts

C. Justification 3: Investment Arbitration advances fairness and the rule of law in the resolution of Investment

Disputes

D. Justification 4: Investment Treaties affirm the Sovereignty and Bargaining Strategies of States

1. Did states carry out a sophisticated cost-benefit analysis?

2. Did developing and transition states appreciate the risks?

3. The role of key actors in promoting the system.

4. Did capital-exporting states appreciate the risks?

E. Justification 5: Investment Treaties were Endorsed by the Democratic Process

V. CONCLUSIONS 


\section{INTRODUCTION}

The treaty-based investment regime incorporates one of the most powerful systems of international adjudication in modern history. This system re-allocates powers from states to multinational companies and from domestic courts to a private arbitration industry based in Washington, New York, London, Paris, The Hague, and Stockholm. ${ }^{1}$ The system remains a recent development in international adjudication, having emerged as a significant decisionmaking process only in the mid-1990s. It is not surprising that there is apprehension about the system and, in turn, that this has generated pressure for reform. The initial source of such pressure in the 1990s was civil society, but a more recent source is the governments of countries against which claims have been brought by investors. For the most part, these are developing or transition countries. It seems likely that new ideas and approaches to the resolution of investment disputes will come from these states. ${ }^{2}$

In this article I canvass a number of issues that arise in debates about the investment regime. The aim is to identify elements of investment treaties and investment arbitration that give cause for concern. The discussion is presented as a series of responses to five justifications offered for the system in academic, trade literature or public commentary. ${ }^{3}$ The main sources for this discussion are the texts of investment treaties, awards of arbitration tribunals, and academic literature. The article does not aspire to a comprehensive or

* Gus Van Harten, Associate Professor, Osgoode Hall Law School, York University, 4700 Keele Street, Toronto, Canada, M3J 1P3, t 416650 8419,

gvanharten@osgoode.yorku.ca, f 4167365736

1 I speak in particular of the roles played in international arbitration by large law firms in these centres; and, more specifically, of the World Bank's International Centre for the Settlement of Investment Disputes (ICSID), the London Court of International Arbitration (LCIA), the International Chamber of Commerce (ICC) and its International Court of Arbitration, the Permanent Court of Arbitration (PCA), and the Arbitration Institute of the Stockholm Chamber of Commerce (SCC).

${ }^{2}$ L.S. Poulsen, Are South-South BITs any Different? A Logistic Regression Analysis of Two Substantive BIT Provisions, Paper for the American Society of International Law Biennial Conference (November 2008); K. Miles, Imperialism, Eurocentrism and International Investment Law: Whereto From Here for Asia?, Paper for the Second Biennial General Conference of the Asian Society of International Law (August 2008) (hereinafter Miles).

3 See, for example, the work of Charles N. Brower, Jan Paulsson, Thomas Wälde, Daniel M. Price, Todd Weiler, Ian A. Laird, Charles H. Brower II, Susan D. Franck, and Stephan Schill. Throughout the paper, I refer periodically to exemplary publications of these and other authors on specific justifications for the system; in this respect, J. PAUlsSON, DENIAL OF JUSTICE IN INTERNATIONAL LAW (Cambridge University Press 2005), at ch. 9 (hereinafter PAUlsson) provides a useful summary of various justifications for the system and is referred to on a number of issues below. Promotional material is also common in informational publications produced by the law firms that work in the field; e.g. S. Noury \& C. Richard (Freshfields Bruckhaus Deringer LLP), International Arbitration in Latin America: Overview and Recent Developments, in InTERNATIONAL COMPARATIVE LEgal Guide to: INTERNATIONAL ARBITRATION 2009, at 282 (Global Legal Group 2009) ("Latin American states for years rejected arbitration due to the suspicion that it granted greater rights to foreign investors.... Over the last 30 years, great advances have been made towards the abandonment of this isolationist policy.... However, the ghost of Dr. Calvo still lingers on in the form of pockets of resistance to arbitration both within the judiciary... and the government."). 
Forthcoming: 2(1) Trade L. \& Dev. 1 (2010).

systematic empirical review nor does it claim to supply any definitive answers to the questions it raises. Rather, the aim is to elaborate some concerns about the system and, in this manner, encourage discussion of a system which, as I among others have argued, ${ }^{4}$ requires reform.

\section{PRESSURE FOR REFORM}

Expectations of reform of the investment regime stem from recent events. First, from the late 1990s, there was an awakening of sorts in the U.S., Canada, and Mexico on the sheer significance of the powers allocated to foreign investors and to arbitrators under NAFTA Chapter $11 .^{5}$ This led to modest but important reforms of NAFTA investment arbitration, including steps to make it more open and to limit the interpretive discretion of arbitrators. ${ }^{6}$ In addition, the U.S. and Canada subsequently revisited their policies on investment treaties in an attempt to clarify loose language on the concepts of expropriation and "fair and equitable" treatment and to expand exceptions for financial measures, for example. ${ }^{7}$ This experience suggested that the NAFTA states did not originally anticipate the full implications of NAFTA Chapter 11. A similar suggestion arose more recently when officials from two major developing states - Pakistan and South Africa - reported that their governments did not appreciate the risks of bilateral investment treaties (BITs) when they were concluded in the 1990 s and that such treaties must receive closer scrutiny. ${ }^{8}$

${ }^{4}$ G. Van Harten, A Case for an International Investment Court, SIEL Working Paper No. 22/08 June 2008), available at: http://papers.ssrn.com/sol3/papers.cfm?abstract_id=1153424; G. VAN HARTEN, InVESTMENT TREATY ARBITRATION AND PubliC LAW (Oxford University Press 2007), at ch. 7 (hereinafter VAN HARTEN-INVESTMENT TREATY ARBITRATION).

${ }^{5}$ North American Free Trade Agreement Between the Government of Canada, the Government of the United Mexican States and the Government of the United States of America, December 17, 1992, 32 I.L.M. 289, at ch. 11 (hereinafter NAFTA). Awareness of these issues also developed via the debate in the mid-1990s over the OECD's proposed Multilateral Agreement on Investment (MAI), a project that was abandoned after France's withdrawal from the negotiations, the expression of reservations by various governments, and widespread opposition from civil society organizations in North and South. C. Lalumière and J. P. Landau, Report on the Multilateral Agreement on Investment (MAI), Interim Report to the Government of France (September 1998); E. Smythe, Domestic and International Sources of Regime Change: Canada and the Negotiation of the OECD Multilateral Agreement on Investment, Paper presented to the Annual Meeting of the Canadian Political Science Association, St. John's, Nfld. (8 June, 1997), at 9-10; A. Walter, NGOs, Business, and International Investment: The Multilateral Agreement on Investment, Seattle, and Beyond, 7 GLOBAL GOVERNANCE 51, 58-60 (2001).

${ }^{6}$ Free Trade Commission (NAFTA), Notes of Interpretation of Certain Chapter 11 Provisions (30 July, 2001), 13(6) WORLD TRADE \& ARB. MATERIALS 139, available at: www.dfait-maeci.gc.ca/tnanac/NAFTA-Interpr-en.asp.

7 A. Newcombe, Canada's New Model Foreign Investment Protection Agreement, 30(14) CanAdiAN COUNCIL ON INT'L L. BULL. (2004), available at: www.ccilccdi.ca/index.php?option $=$ com_content\&task $=$ view\&id $=89 \&$ Itemid $=112$; See also the "May $10^{\text {th" }}$ U.S. Administration-Congressional Agreement on Trade Policy, reproduced in the letter of May 10, 2007 from the Chairs of the U.S. House of Representatives' Committee on Ways \& Means and Subcommittee on Trade to the U.S. Trade Representative, available at: http://waysandmeans.house.gov/Media/pdf/110/05\%2014\%2007/05\%2014\%2007.pdf.

8 Republic of South Africa, infra note 55, 95. 
More recently, a tentative trend toward more fundamental reform has emerged in Latin America. ${ }^{9}$ In 2007, Bolivia withdrew from the International Centre for Settlement of Investment Disputes (ICSID) and Ecuador excluded disputes over natural resources from its consent to the ICSID Convention. ${ }^{10}$ In July 2009, Ecuador went further and denounced the ICSID Convention outright. ${ }^{11}$ Venezuela withdrew from its BIT with the Netherlands (whose BITs have been used by forum-shopping investors to bring claims against the opposite state party via holding companies in the Netherlands). ${ }^{12}$ Various states have also announced plans to establish an arbitration forum within the Union of South American Countries (UNASUR) as an alternative to ICSID. ${ }^{13}$ Governments have also pushed foreign investors to renegotiate investment contracts, especially in the resource sector, and have reportedly modified their approach to investment contracts so as to require foreign investors to waive their right to pursue investment treaty arbitration in the event of a dispute arising from the contract. ${ }^{14}$

Perhaps most importantly, in 2008, Ecuador terminated eight BITs which were deemed to be unsuccessful in stimulating new investment ${ }^{15}$ and, in October 2009, President Rafael Correa reportedly proposed to the country's Congress that Ecuador should withdraw from 13 additional BITs dating from the 1990s. ${ }^{16}$ These include Ecuador's BITs with six conventional capital-exporters in Europe and North America (U.S., U.K., Germany, France, the Netherlands, and Canada) ${ }^{17}$ as well as China. Ecuador's stance apparently reflects a wider policy choice to accept foreign investment from China as an alternative to Western capital. It remains to be seen whether China is prepared to make such investment without requiring the treaty-based protections sought and designed by the West and whether China will rely on other means to avoid or manage political risks.

9 I.A. Vincentelli, The Uncertain Future of ICSID in Latin America, Research paper (2009), available at: http://works.bepress.com/ignacio_vincentelli/1.

${ }_{10}$ Convention on the Settlement of Investment Disputes Between States and Nationals of Other States, 18 March, 1965, 4 I.L.M. 524 (hereinafter ICSID Convention). L.E. Peterson, Ecuador becomes second state to exit ICSID system; IAReporter review finds that approximately two-thirds of treaty claims against Ecuador have been brought to ICSID, 2(12) INVESTMENT ARB. REP. (17 July, 2009), available at: www.iareporter.com.

${ }^{11}$ F. Cabrera Diaz, Ecuador prepares for life after ICSID, while debate continues over effect of its exit from the Centre, INVESTMENT TREATY NEWS (September 2009) at 3.

${ }^{12}$ L.E. Peterson, Venezuela surprises the Netherlands with termination notice for BIT; treaty bas been used by many investors to "route" investments into Venezuela, 1(1) INVESTMENT ARB. REP. (16 May, 2008), available at: www.iareporter.com.

${ }^{13}$ F. Cabrera Diaz, South American alternative to ICSID in the works as governments create an energy treaty, INVESTMENT TREATY NEWS (6 August, 2008).

14 A. Romanetti, Preventing the Abuse of Multiple and Concurrent Arbitration Proceedings: Waiver Clauses, Draft paper (2009)

15 These steps by Ecuador are especially important because they remove the state's underlying consents to the compulsory arbitration of investor claims and because they do so in relation to treaties that apply to large amounts of capital flows or potential capital flows into Ecuador. In doing so, they return Ecuador to the legal position that it occupied before 1995 when the first of its BITs with a major capital-exporter (the UK) was concluded; L.E. Peterson, Ecuadorian President reportedly asks Congress to terminate 13 BITs; move comes on beels of earlier termination of multiple BITs, 2(17) INVESTMENT ARB. REP. (30 October, 2009).

16 UNCTAD, Country-specific list of BITs, available at: www.unctad.org/Templates/Page.asp?intItemID=2344\&lang=1 (hereinafter UNCTAD List). ${ }_{17}$ Major Capital-Exporters, infra note 22. 
It should be stressed that, even in Latin America, this push back against the system, while very significant, does not necessarily reflect a broad movement in the region (given the ongoing adherence of other countries, especially Argentina, to their treaties and to ICSID). Even so, these recent developments reflect widespread doubts about the system. The arbitration mechanism, especially, has gained notoriety as more investors have brought aggressive claims against governments in matters of general public policy, as arbitrators have adopted expansive readings of their own jurisdiction and of substantive standards under the treaties, ${ }^{18}$ and as some very large awards have been issued against states. ${ }^{19}$

The timing of recent reforms is also significant. Some argue that it reflects a wider malaise of the corporate neoliberal model - based on the upward transfer of wealth, constraint of government, and liberalisation of markets ${ }^{20}$ - that has been associated with Anglo-American and Bretton Woods politics since the 1980s. ${ }^{21}$ Investment treaty arbitration is an important legal and institutional piece of the neoliberal puzzle because it imposes exceptionally powerful legal and economic constraints on governments and, by extension, on democratic choice, in order to protect from regulation the assets of multinational firms. It is unlikely that the break-out period of BITs in the late 1980s and early 1990s coinciding with the heyday of the Washington Consensus was a coincidence. This was a period in which large numbers of treaties were concluded by disparate countries with the cumulative effect of expanding the system well beyond its origins in the treaty networks of the 12 major capitalexporters (even if those treaty networks remain the core of the system in that they have generated roughly $90 \%$ of known investor claims). ${ }^{22}$

18 D. Schneiderman, Constitutionalizing Economic Globalization 71-73, 95-108 (Cambridge University Press 2008) (hereinafter SCHneIDERMAN); B. Choudhury, Recapturing Public Power: Is Investment Arbitration's Engagement of the Public Interest Contributing to the Democratic Deficit?, 41 VAND. J. TRANSNAT'L L. 775, 793-95 (2008) (hereinafter Choudhury).

${ }^{19}$ E.g. Ceskoslovenska Obchodni Banka v Slovak Republic (24 May, 1999), 14 ICSID REV. 251, 17(3) WORLD TRADE \& ARB. MATERIALS 189 (\$1.05 billion (U.S.; all amounts in this footnote are approximated including interest)); CME Republic BV v Czech Republic (13 September, 2001), 14(3) WORLD TRADE \& ARB. MATERIALS 109 (\$350 million); CMS Gas Transmission Company v Argentine Republic (12 May, 2005), 44 I.L.M. 1205, 17(5) WORLD TRADE \& ARB. MATERIAls 63 (\$149 million).

20 D. Harvey, A Brief History of NeOliberalism 15-19 (Oxford University Press 2005).

${ }^{21}$ M. Sornarajah, The Clash of Globalizations and the International Law on Foreign Investment, Paper for the Norman Paterson School of International Affairs Simon Reisman Lecture in International Trade Policy, Ottawa (12 September, 2002), available at: http://www.carleton.ca/ctpl/pdf/papers/sornarajah.pdf; I.T. Odumosu, The Antinomies of the (Continued) Relevance of ICSID to the Third World, 8 SAN DIEGO INT'L L.J. 345 (2007); S. Spronk \& C. Crespo, Water, National Sovereignty and Social Resistance: Bilateral Investment Treaties and the Struggles against Multinational Water Companies in Cochabamba and El Alto, Bolivia, 1 L., SOC. JusT. \& GLOBAL DEV. J. (2008), available at: http://www.go.warwick.ac.uk/elj/lgd/2008_1/spronk_crespo.

22 These 12 major capital-exporters are the U.S., U.K., Germany, France, the Netherlands, Hong Kong, Switzerland, Japan, Spain, Belgium, Canada, and Italy. The 12 are listed in order of total FDI outward stock for 2008 as reported in UNCTAD, World Investment Report 2009, 251-54 (New York and Geneva, United Nations, 2009) (hereinafter Major Capital-Exporters). In my own informal tracking of 396 known treaty-based claims where the relevant data was reported in publicly available awards or in news reporters (Investment Arbitration Reporter, Investment Treaty News) as of May 2009, I found that $90 \%$ (357) of the claims were brought by a national of one of these 12 capital-exporters against a developing or transition country pursuant to a BIT between the two states, to NAFTA, or to the Energy Charter Treaty (annex I of the Final Act of the European Energy Charter Conference) 
In 1989, according to UNCTAD, there were 385 BITs, whereas by 1995 there were 1173, and by 2000 there were 1941 (although not all were in force). ${ }^{23}$ In Latin America, by 1989, just two countries (Belize and Panama) had agreed to a compulsory investor-state arbitration mechanism in a BIT with one of the 12 major capital-exporters; by 2005, another 10 countries in the region had done so (Uruguay, Bolivia, Argentina, Paraguay, Peru, Venezuela, Chile, Mexico, Ecuador, and Nicaragua). ${ }^{24}$ Among the emerging economies of China, India, and Brazil, only the former - which ratified numerous BITs in the 1980s as part of its economic liberalisation reforms of the period - had concluded a BIT with a major capital-exporter before 1990, and only after 2000 did China incorporate broad consents to investor-state arbitration in such treaties. ${ }^{25}$ India's first BITs with a major capital-exporter came into force only in 1998 (with Germany and Italy, both signed in 1995) whereas Brazil has declined to ratify any BITs. ${ }^{26}$

Even so, whether for reasons of ideology or rational choice ${ }^{27}$ and whether as a response to structural pressures at the international level ${ }^{28}$ or state capture by domestic economic elites, ${ }^{29}$ most countries joined the present regime in the 1990s. In doing so, they endorsed international arbitration as a governing arrangement to regulate and discipline their governments on behalf of foreign investors (but not vice versa) more directly and more comprehensively than any international adjudicative regime since the colonial era. ${ }^{30}$

\section{FOCUS ON "MUSCULAR" INVESTMENT TREATIES}

In examining this system, the discussion in this article focuses on five justifications commonly offered to support the system in its bold but nevertheless widespread form. Looking primarily at the treaties concluded by the major European and North American

(Lisbon, 17 December, 1994; 34 I.L.M. 373). Note that I did not attempt to account for forumshopping in collecting this descriptive data. Note also that Hong Kong and Japan accounted for none of the 357 claims.

${ }^{23}$ UNCTAD, Quantitative data on bilateral investment treaties and double taxation treaties (2002), available at: www.unctad.org/templates/WebFlyer.asp?intItemID=3150\&lang=1.

${ }^{24}$ UNCTAD List, supra note 16.

25 These included BITs with three major capital-exporters (U.K., Japan, and Italy) during 1986-89. However, China did not conclude any further BITs with the major capital-exporters until after 2000. Since that year, three BITs between China and Germany, Spain, and the Netherlands, respectively, have been signed and entered into force. UNCTAD List, supra note 16. On the BRIC countries and the investment treaty system, see M. Mortimore \& L. Stanley, Justice Denied: Dispute Settlement in Latin America's Trade and Investment Agreements, Working Group on Development and Environment in the Americas Discussion Paper No. 27 (October 2009), at 24-32, available at: http://ase.tufts.edu/gdae/WorkingGroup.htm (hereinafter Mortimore \& Stanley).

${ }^{26}$ UNCTAD List, supra note 16.

27 A. Guzman, Why developing countries sign treaties that hurt them: Explaining the popularity of BITs, 38 VA. J. INT'L L. 553 (1998); R.J. Bubb \& S. Rose-Ackerman, BITs and bargains: Strategic aspects of bilateral and multilateral regulation of foreign direct investment, 27 INT'L REV. L. \& ECON. 291 (2007).

${ }^{28}$ Z. Elkins, A.T. Guzman \& B.A. Simmons, Competing for Capital: The Diffusion of Bilateral Investment Treaties, 1960-2000, 60 INT’L ORG. 811 (2006) (hereinafter Elkins, Guzman \& Simmons).

${ }^{29}$ L. Collinson, Explaining Pareto-Inefficient International Cooperation Using Argentina's Bilateral Investment Treaties, DESTIN Working Paper No. 08-87 (2008), at 22-5, available at: www.lse.ac.uk/collections/DESTIN/pdf/WP87.pdf (hereinafter Collinson). 30 VAN HARTEN-INVESTMENT TREATY ARBITRATION, supra note 4, at ch 2. 
capital-exporters - whose nationals have brought the great majority of known claims ${ }^{31}-$ as interpreted (often expansively) by investment arbitration tribunals, one may identify these "muscular" elements of the system:

- investors are authorised to bring claims against states in relation to most or all aspects of the treaty rather than a more limited class of potential disputes, such as those involving the amount of compensation to be paid in the event of an expropriation.

- investors can bring claims in arbitration forums at which voting power is concentrated in the major capital-exporting states (e.g. the World Bank) or an international business organisation (e.g. the International Chamber of Commerce).

- investors can bring claims without having to exhaust local remedies in the host state, regardless of whether those remedies are capable of delivering justice.

- investors can submit contractual disputes with the host state or a state entity to the arbitration mechanism under the investment treaty, even where the contract itself requires the resolution of disputes in another forum.

- investors can forum-shop, i.e. they can acquire the status of a "foreign investor" under a treaty merely by establishing a holding company in a state party to that treaty.

- arbitrators are authorised to regulate and discipline states based on broadly framed standards, such as protections from "unfair" or "inequitable" treatment and from "expropriation" or "deprivation";

- arbitrators are authorised to review the conduct of virtually any branch or entity of the state;

- arbitrators are authorised to award money damages, as opposed to conventional public law remedies, where the state is found retrospectively to have violated its treaty obligations;

- host states submit to pre-establishment national treatment for foreign investors rather than simply post-establishment non-discrimination. ${ }^{32}$

- host states submit to a most-favoured-nation (MFN) clause that is open to expansive interpretation by arbitrators such that it incorporates procedural and substantive elements in other investment treaties as requirements of MFN treatment.

31 Major Capital-Exporters, supra note 22.

32 This element is limited to the U.S. model of investment treaty (which was emulated by Canada after NAFTA) although European countries have sought to incorporate this element into their treaty networks by concluding Economic Partnership Agreements (EPAs) that adopt a positive list approach to pre-establishment national treatment as a complement to existing BIT networks of European states. G. Van Harten, Investment Provisions in Economic Partnership Agreements, Research paper (March 2008), available at: http://papers.ssrn.com/sol3/papers.cfm?abstract_id=1461110. 
- foreign states are authorised to enforce an award against an unsuccessful state based on the recognition and enforcement provisions of the ICSID Convention, the New York Convention, and/or the Panama Convention. ${ }^{33}$

Most investment treaties incorporate many of these elements; many investment treaties reflect all or virtually all of them. These elements have all been defended, explicitly or implicitly, by advocates of the system, many of whom - it is important to highlight - are part of or closely connected to the investment arbitration industry. ${ }^{34}$ Moreover, advocates of the system usually do not differentiate between these elements of the treaties so as to reject one or another muscular component. ${ }^{35}$ Rather, most advocates tend to promote the system as a whole and, if they do differentiate among these elements, they tend to favour the system in its bold form. For these reasons, it is appropriate to focus on this muscular version of the treaties in a discussion of justifications for the system.

\section{DISCUSSION}

\section{A. Justification 1: Investment Treaties are a means to encourage Foreign Investment}

A common argument in support of the system is that it is a means for states to encourage foreign investment into their territory (especially from the other state party to the treaty). ${ }^{36}$ Thus, we might say that Ecuador, wishing to encourage investment from the U.S., could conclude an investment treaty with the U.S. in order to signal its commitment to accept and protect U.S. investors, thus encouraging them to invest in Ecuador rather than another locale. The logic may appear almost self-evident. However, there are number of difficulties

33 ICSID Convention, supra note 10; United Nations Convention on the Recognition and Enforcement of Foreign Arbitral Awards (New York, 10 June, 1958, 330 U.N.T.S. 3, entered into force 7 June, 1959) (hereinafter the New York Convention); Inter-American Convention on International Commercial Arbitration (Panama, 30 January, 1975, 14 I.L.M. 336) (hereinafter the Panama Convention).

${ }^{34}$ By "investment arbitration industry", I refer broadly to persons who sit as investment arbitrators; to key actors in the major organizations for international commercial and investment arbitration, such as the International Chamber of Commerce, the London Court of International Arbitration, and the Stockholm Chamber of Commerce; and to lawyers and legal experts who derive substantial income from the litigation of investment treaty claims. Notably, the business model of the industry is built essentially on the payment of legal and arbitration fees by claimants and by states and on the promise of payment of compensation to investors, especially by governments of developing and transition countries.

35 Supra note 3.

36 See, for example, R. Dolzer, The Impact of International Investment Treaties on Domestic Administrative Law, 37 INT’L L. \& POL. 953, 953-54 (2005) (hereinafter Dolzer); PAULSSON, supra note 3, at 240 ("The occasional costs of having offered international protection of investors' rights appear minuscule compared to the macroeconomic effects of the treaty overall"). For a useful discussion of this explanation for investment treaties and possible implications of it being unsupported by compelling evidence, see J.W. Salacuse, The Treatification of International Investment Law, 8 STUD. INT'L FIN. ECON. \& TECH. L. 241, 245 (2007) (hereinafter Salacuse); K. J. Vandevelde, A Brief History of International Investment Agreements, 12 U.C. DAVIS J. INT'L L. \& POL’Y 157 (2005). 
with this justification, arising both from the text of investment treaties and from the empirical evidence.

Here, let me highlight three points about the text of investment treaties which raise difficulties. The first is that many of the treaties take a liberal approach to forum-shopping. Put differently, they allow owners of assets to pick and choose among nationalities at their convenience for the purpose of bringing investment treaty claims against countries in which they own assets. An investor may acquire the nationality of a state party to the treaty, thus gaining access to the treaty, merely by setting up a holding company in that state. Likewise, an investment that was originally domestic - in that it was owned by nationals of the state in question - can be made "foreign" merely by a paper transfer of ownership to a foreign entity. ${ }^{37}$ Most surprisingly (based on an expansive jurisdictional ruling by two of the three arbitrators in Tokios ${ }^{38}$ ) a domestic business can apparently make itself "foreign" so as to bring a claim against its own country simply by creating a holding company in a state that is party to a BIT with the home country.

There are various explanations and rationales for the strange decision of states to allow this legal maneuvering and gaming by investors. Yet if the aim of investment treaties is to encourage foreign investment between the states parties to the treaty - and not to extend special legal rights and privileges broadly to an international class of corporate owners of assets - then the expansive approach to forum-shopping that is enabled by broad language in many of the treaties and, in turn, by the permissive interpretations of some arbitrators makes no sense. Indeed, it undermines the entire conceptual framework for the negotiation of investment treaties whose purpose is simply to encourage investment flows between the territories of the states parties to the treaty.

A second point that calls into question this justification is that few, if any, investment treaties place enforceable obligations on the home states of investors to encourage or facilitate outward investment by, for instance, liberalizing their own regulatory regimes or enhancing their programs for investment insurance. This is anomalous if the purpose of an investment treaty is indeed to encourage capital flows between the states parties. Home states might, for instance, commit to subsidizing regulatory risk insurance for investments that are covered by the treaty. Further, they might require the use of that insurance to supplement the compensatory regime of the treaty in cases where an investor has suffered losses due to general regulatory activity by the host state. On this basis, the regulatory risks that are inherent in foreign investment, and in all forms of business decision-making in the face of changing social, economic, and environmental conditions, would be shared between host and home state. Instead of obligating home states to take such steps, investment treaties typically establish subrogation rights of political risk insurance or guarantee programs in order to allow the home country to step into the shoes of the investor in advancing a claim against the host country. ${ }^{39}$ In this respect, the purpose appears to be more about protecting the economic position of home states where a dispute has arisen between one of its nationals and another state than about encouraging investment flows.

A third point concerning the texts of investment treaties is that most of them apply to existing investments. However, if the purpose of the treaty is to attract investment, why

${ }^{37}$ Fedax NV v Republic of Venezuela (11 July, 1997), 5 ICSID REP. 186, 37 I.L.M. 1378.

${ }^{38}$ Tokios Tokelès v Ukraine (29 April, 2004), 20 ICSID REV. 205, 16(4) WORLD Trade \& ARB. MATERIALS 75 (hereinafter Tokios).

39 R. Dolzer \& M. Stevens, Bilateral Investment Treaties 156 (Kluwer Law International 1995). 
apply it to investments that have already been attracted? One might expect that capitalimporting states would prefer not to extend an investment treaty to existing investments, limiting it instead to new investments and to re-investments in the host economy by existing investors. Why would a state make extensive legal concessions, and put the state treasury at significant risk, in the case of investments already won?

Of course, various explanations could be offered. One is that the major capital-exporters were aggressive in insisting that existing investments be protected and that all (or virtually) capital-importing countries gave into this pressure over the course of the hundreds of investment treaties now in force. Another explanation is that capital-importers were driven by an ideological commitment to openness and to the attraction of foreign capital, whether or not the investments were already in place. Another is that these states were not well informed about what they were negotiating and, as a result, made bad decisions. I do not suggest that any of these explanations is particularly compelling. All or none of them might play a role in the experiences of different countries and treaties. But this and other features of the great majority of investment treaties casts doubt on the explanation that states concluded such treaties so as to encourage foreign investment.

Doubts about this justification for investment treaties are supported by the fact that empirical research to date is at best mixed on the issue of whether the treaties actually encourage investment. I have reviewed eight empirical studies on the proposition that they do encourage investment, of which five found little or no positive connection between the conclusion of investment treaties and an increase in foreign direct investment. To summarize, in 1998, UNCTAD concluded that BITs played a "minor and secondary role in influencing FDI flows". ${ }^{40}$ In a comprehensive study, Hallward-Dreimeier analyzed FDI flows from OECD to developing countries during 1980-2000 and found a "significant negative finding on the impact of ratifying a BIT". ${ }^{41}$ Tobin and Rose-Ackerman found that BITs have "little impact" on the attraction of FDI, although they may have an impact in countries with higher political risks, and that "signing a BIT with the United States does not correspond to increased FDI flows". ${ }^{42}$ Salacuse and Sullivan, in contrast, find a positive effect on FDI flows for U.S. BITs but less so for BITs concluded by other OECD countries. ${ }^{43}$ Neumayer and Spess in a 2005 study found a positive and statistically significant effect of BITs on FDI flows and that, the greater the number of BITs signed with capitalexporting countries, the greater the amount of FDI, thus offering "the first hard evidence that there is a payoff to a developing country's willingness to incur the costs of negotiating

${ }^{40}$ UNCTAD, Bilateral Investment Treaties in the Mid-1990s, UN Doc. UNCTAD/ITE/IIT/7 (1998), at $141-2$.

${ }^{41}$ M. Hallward-Dreimeier, Do Bilateral Investment Treaties Attract Foreign Direct Investment? Only a Bit... and They Could Bite, World Bank Policy Research Working Paper 3121 (2003), at 19.

42 J. Tobin \& S. Rose-Ackerman, Foreign Direct Investment and the Business Environment in Developing Countries: The Impact of Bilateral Investment Treaties, Center for Law, Economics and Policy Research Paper No. 293, Yale Law School (2004) at 19, 22, 31. In a second study, using new data, the authors concluded that the number of BITs that a country has signed with a high income country affected positively the amount of FDI inflow, but that the marginal benefit of an extra BIT to the host country declined as more and more countries concluded investment treaties. J. Tobin \& S. RoseAckerman, Bilateral Investment Treaties: Do They Stimulate Foreign Direct Investment?, available at: http//ssrn.com (2006) at 18-21.

${ }^{43}$ J.W. Salacuse \& N.P. Sullivan, Do BITs Really Work?: An Evaluation of Bilateral Investment Treaties and Their Grand Bargain, 46 HARV. INT'L L.J. 67 (2005). 
BITs and to succumb to the restrictions on sovereignty". ${ }^{44}$ Yet, applying Neumayer and Spess' model, Yackee found the relationship of BITs to FDI flows to be marginal and much smaller than Neumayer and Spess suggested and that their findings "rest on quite unstable ground" and "are far less robust" than a casual reading of their study would suggest. ${ }^{45}$ Finally, in a recent qualitative study, Poulsen used qualitative evidence based on interviews with political risk insurers to supplement the quantitative studies to date and concluded that; ${ }^{46}$

“... quantitative and qualitative data currently available suggests that while BITs undoubtedly play a role in some investment projects, they are highly unlikely to be a determining factor for the vast majority of foreign investors determining where, and how much, to invest."

Thus, there is, at best, conflicting evidence that investment treaties actually encourage foreign investment (and in turn that any signalling effect of the treaties has actual effects on investor decision-making about where to commit capital). As such, and in light of the risks assumed by states under the treaties, it is dubious, not to say reckless, for anyone to assert today that the treaties are a vehicle to encourage actual investments. Also, it is clear that in the 1990s - when so many of the treaties were concluded - there was no empirical evidence that they served this stated purpose. Most states therefore committed themselves to what are arguably the most financially risk-laden international obligations in the world today without a credible empirical basis for the claim that the treaties would achieve their stated purpose.

In the 1990s, one could claim reasonably that a lack of evidence about the benefits of investment treaties was matched by a lack of evidence about their risks. There were only a handful of investment treaty awards against states prior to the mid-1990s and there was arguably limited understanding of the scope of the general and prospective consents of states to compulsory arbitration. ${ }^{47}$ Since the explosion of claims in the late 1990s, however, hundreds of additional treaties have been concluded. Why would states continue to conclude (or decline to withdraw from) a treaty model for which there was no evidence that they actually encouraged investment, while carrying serious risks and liabilities for states? One explanation is that the encouragement of investment is not a key consideration for governments that have continued to conclude more and more treaties. If the aim was to encourage investment, those states would presumably have taken steps to enhance the role of the treaties in this respect. Alternatively, one may conclude that it simply takes time for evolving knowledge and evidence about the system to influence official decision-making.

Whatever the explanation, the key point is that this justification for the system is contradicted by a number of common provisions in investment treaties and unsupported by

${ }^{44}$ E. Neumayer \& L. Spess, Do bilateral investment treaties increase foreign direct investment to developing countries?, at 5, LSE Research Online, available at: http://eprints.lse.ac.uk/archive/00000627.

${ }^{45} \mathrm{~J} . \mathrm{W}$. Yackee, Sacrificing Sovereignty: Bilateral Investment Treaties, International Arbitration, and the Quest for Capital, USC Center in Law, Economics and Organizational Research Paper No. C06-15 (2006), at 51.

${ }^{46}$ L.S. Poulsen, The Importance of BITs for Foreign Direct Investment and Political Risk Insurance: Revisiting the Evidence, in YEARBOOK ON INTERNATIONAL INVESTMENT LAW AND POLICY 2009/2010 (K. Sauvant ed., forthcoming 2010).

47 C. McLachlan, Commentary: The Broader Context, 18 ARB. INT’L 339, 340 (2002). 
the preponderance of empirical evidence. If this justification was a major factor in the decisions of many states to conclude investment treaties - or of international organizations to promote the investment treaty model - then these decisions appear to have been based on incomplete knowledge about the expected linkages between the treaties and capital flows. Likewise, in the absence of stronger evidence that the treaties actually encourage investment, a major plank in the wider case for the treaties as contributors to sustainable development and to social welfare falls away. ${ }^{48}$

\section{B. Justification 2: Investment Treaties respond to the Bias and Unreliability of Domestic Courts}

It is often pointed out by advocates for investment treaty arbitration that domestic remedies in developing and transition states, and even in developed states, are inadequate because they take much too long, are biased, are corrupt, or are otherwise unreliable. ${ }^{49}$ In its more aggressive form, this argument mutates into a rejection of courts in general because the judicial process entails too careful and time-consuming consideration of a dispute and too many opportunities for appeal, to permit the desired speed and clarity in business decisionmaking. More commonly, however, this justification is not framed so as to condemn all courts as biased against foreign investors. It is said, rather, that the courts of some countries are non-functional or biased or corrupt so as to make them unreliable, and on this at least there can be little doubt (without going so far as to name particular countries). Domestic legal systems may be inaccessible or take too long; judges may be corrupt or otherwise incapable of ensuring fairness.

As a matter of principle, states should work to address this problem for all investors, domestic or foreign, and indeed for all citizens. Those who promote investment treaties as a response to the weaknesses of domestic legal systems, therefore, might also be expected to champion provisions in investment treaties that seek to address the unreliability of courts for investors and non-investors alike. The treaties could, for example, allow citizens that have a grievance against a foreign investor - due to major environmental damage or human rights abuse that it has allegedly caused, for example ${ }^{50}$ - to bring an international claim against the investor where the domestic legal system does not offer them an expeditious and fair process. Likewise, in the absence of broader access by non-investors to the process of international adjudication of investment disputes, it might be acknowledged that investment arbitration itself appears unfair. This is because fairness usually calls for all parties that are affected by the resolution of a dispute to be given standing in the adjudicative process and because, in investment treaty arbitration, only one class of private interests - the investor has the right to be heard directly. Others affected by the conduct of the state or of the investor are barred from party status and thus from the right to introduce evidence, make

48 J.E. Stiglitz, Multinational Corporations: Balancing Rights and Responsibilities, 101 AM. SOC'Y INT'L L. PROC. 3, 4 (2007).

${ }^{49} \mathrm{~J}$. Paulsson, Enclaves of Justice, Presentation to the Rule of Law Conference, University of Richmond School of Law (12 April, 2007); T.W. Wälde, The Present State of Research Carried Out by the EnglishSpeaking Section of the Centre for Studies and Research, in NEW ASPECTS OF INTERNATIONAL InVESTMENT LAW 63, 77-78 (P. Kahn \& T.W. Wälde eds., Martinus Nijhoff Publishers 2007) (hereinafter Wälde).

${ }^{50}$ Miles, supra note 2, at 4-5. 
submissions, and otherwise participate fully in the process. ${ }^{51}$ If domestic remedies are unreliable, then why allow investors alone to take part in the international adjudicative process?

The response of the treaties to this rationale for the system are therefore underinclusive. It extends the benefits of international arbitration to a narrow class of private actors, giving foreign investors the unique opportunity to resort to domestic or international options (or both) as they prefer. Of course, not all foreign investors are well positioned by the system to bring a claim against a state that has abused them in some way. ${ }^{52}$ The cost of access, in particular, precludes many foreign investors ever from bringing a claim. ${ }^{53}$ On the other hand, there is a class of large firms that have substantial wealth wrapped up abroad which can utilize the system in a range of potent ways. Most problematically, when one considers the lack of access by other interests in the process, large firms are uniquely positioned to use the system in order to challenge state measures that are aimed generally at advancing a development strategy, stabilizing the financial system, promoting human rights, protecting public health and the environment, etc. ${ }^{54}$

This raises a second difficulty with the present justification in light of the system's design. The treaties are over-inclusive because they do not account for situations in which domestic courts do offer justice to a foreign investor. ${ }^{55}$ By removing the duty to exhaust local remedies unconditionally, many investment treaties allow investors to turn their back entirely on domestic law or, ${ }^{56}$ indeed, to game the system by bringing multiple claims under the treaty (or multiple treaties ${ }^{57}$ ) and in domestic courts. ${ }^{58}$ The investor has the sole discretion, unlike in other treaty regimes that allow individual claims, to decide on the reliability, suitability, and so on of the alternative remedies. Combined with the permissive approach to forum-shopping endorsed by most of the arbitration tribunals, this allows much maneuvering by corporate lawyers to maximize the pressure on host governments and thus enhance the prospect of public compensation for their clients. This gives immense power to a class of large foreign investors that is unavailable to other investors and, of course, to citizens and communities in general.

Based on this justification for the system, then, one would expect a rational connection between the treaty provisions and the purported rationale. If the concern was that domestic courts systems in some countries are unreliable, then the duty to exhaust local

${ }^{51}$ J. Alvarez, Critical Theory and the North American Free Trade Agreement's Chapter Eleven, 28 U. MiAMI INTER-AM. L. REV. 303, 307-09 (1997).

$52 \mathrm{~J}$. Kurtz, The Use and Abuse of WTO Law in Investor-State Arbitration: Competition and its Discontents, 20 EUR. J. INT'L L. 749, 758 (2009).

53 Wälde, supra note 49, at 87-88.

${ }^{54}$ L.E. Peterson, The Global Governance of Foreign Direct Investment: Madly Off in All Directions, Dialogue on Globalization Occasional Paper No. 19 (Geneva: Friedrich Ebert Stiftung, May 2005) at 17-21.

55 Republic of South Africa, Bilateral Investment Treaty Policy Framework - Government Position Paper (Pretoria: Department of Trade and Industry, June 2009), at 45 (hereinafter Republic of South Africa).

56 In the absence of a fork-in-the-road clause applied robustly by the arbitration tribunal (many tribunals have interpreted away such clauses where the domestic claims were pursued by a different corporate entity from, although it was closely related to, the company that brought the treaty claim).

${ }^{57}$ Lauder (Ronald S) v Czech Republic (3 September, 2001), 4 WORLD TRADE \& ARB. MATERIALS 35 (2002); CME Republic BV v Czech Republic (13 September, 2001), 14(3) WorLD TrADE \& ARB. MATERIALS 109.

58 Infra note 107. 
remedies should be removed selectively in such circumstances. Or, at least, the treaties should allow a state to demonstrate - based on a rigorous threshold - that its legal system does offer justice to a foreign investor, as a basis for removing a tribunal's jurisdiction over the claim. Likewise, the question of the reliability of the host country's courts should be decided by an independent tribunal, and not by the foreign investor or the state.

Yet we do not see such provisions in the treaties. Instead, the duty to exhaust local remedies is removed unconditionally, ${ }^{59}$ even for countries that have mature and advanced systems of justice; indeed, it is removed for systems that far surpass investment arbitration itself for their institutionalized fairness, openness, and independence. Also, the treaties remove the duty to exhaust local remedies in the case of developing and transition states that do offer high standards of access to justice or that have made major advances in this direction. As a result, the treaties do not leave space for recognition and acknowledgement of variations in the quality of domestic legal systems.

C. Justification 3: Investment Arbitration advances fairness and the rule of law in the resolution of Investment Disputes

The next justification is connected to the criticism of domestic legal systems that is implicit in the unconditional removal of the duty to exhaust local remedies, as discussed above. It is the further claim that investment treaties have replaced domestic law and courts with a fair, independent, and neutral process of adjudication to resolve investor-state disputes and that the system advances the rule of law. ${ }^{60}$ This is a dubious claim, as I have argued elsewhere, ${ }^{61}$ if we assume that the rule of law rests on high standards of procedural fairness in adjudication (and, as such, institutional safeguards of independence), especially at the final level of adjudicative decision-making. The problem is that, on close scrutiny, the system of investment treaty arbitration does not satisfy this requirement of the rule of law.

The problem is unique to investment treaty arbitration because it is a form of (formally non-reciprocal) public law adjudication and because investment treaty arbitrators lack institutional safeguards of their independence, especially security of tenure. This would not be a major issue if the matters decided by the arbitrators were minor concerns or subject to thorough review by an independent court. Neither is true however. Investment treaty arbitrators often resolve, on a final basis, fundamental matters of public law without the prospect of close scrutiny by independent judges, whether domestic or international. As a result, longstanding safeguards of judicial independence in domestic systems of justice have

${ }^{59}$ Or with very limited conditions such as a 6-month duty of the investor to seek (but without any duty to obtain) a friendly resolution of the dispute.

${ }^{60}$ C.N. Brower \& L.A. Steven, Who Then Should Judge? Developing the International Rule of Law under NAFTA Chapter 11, 2 CHI. J. INT'L L. 193, 195-97, 200-02 (2001) (hereinafter Brower \& Steven); S.D. Franck, Foreign Direct Investment, Investment Treaty Arbitration, and the Rule of Law, 19 GLOBAL BUS. \& Dev. L.J. 337, 340 (2007); Z. Douglas, Nothing if Not Critical for Investment Treaty Arbitration: Occidental, Eureko and Methanex, 22 ARB. INT'L 27, 27, 51 (2006); Dolzer, supra note 36, at 971-72; PAULSSON, supra note 3, at 265; Salacuse, supra note 36, at 247; Wälde, supra note 49, at 95, 101-02; I.A. Laird, NAFTA Chapter 11 Meets Chicken Little, 2 CHI. J. INT’L L. 223, 229 (2001) (hereinafter Laird).

61 G. Van Harten, Investment Treaty Arbitration, Procedural Fairness, and the Rule of Law, in International Investment LaW and Comparative Public LaW (T. Wälde \& S. Schill eds., Oxford University Press (forthcoming 2010). 
been abandoned in the unique context where foreign investors bring international claims against states and, by extension, the people who are represented by states.

Security of tenure is one of the core safeguards of adjudicative independence in public law. ${ }^{62}$ It is not an "artificial" attribute of judging (as was suggested to me by one arbitrator at a conference in $2008^{63}$ ); rather, in the Western liberal tradition, it has for centuries been central to the notion of judicial independence both from powerful private interests and from other branches of the state. It emerged as a response to abuse of power by kings and queens and, as such, it forms part of the institutional apparatus that has limited and refined sovereign power in the modern state. By removing it, as investment treaties clearly do, states have returned us to a model of adjudicative decision-making that is directly dependent on the discretion of executive officials in powerful governments and, remarkably, in international business organizations and in the arbitration industry. That is a strange way to promote the rule of law if this was indeed an aim of the investment treaty system.

Combined with other institutional safeguards of judicial independence - including the state's provision of a set salary for the judge, bars on outside remuneration, and an objective means of allocating adjudicators to specific cases - security of tenure insulates judges from the appearance of inappropriate pressure on their decision-making and, by extension, allows the courts to provide a foundation for the rule of law. Without secure tenure for the judges who decide public law, one must ask, where does the judge's career interest lay? Where one can credibly show that the judges may be financially or economically beholden to public or private interests that have a stake in the case or in the interpretation of the law, then the appearance of independence - and appearances are key in this respect given the difficulties of proving or disproving actual bias ${ }^{64}-$ is seriously undermined.

What is wrong with investment treaty arbitration in this respect? The first problem is that the system is a one-way process of public law claims where only one class of parties (the investors) triggers use of the system by bringing claims, and only the other class (states) is liable to pay awards for violating the treaty. Unlike in other situations where arbitration is used, the ability to bring claims is non-reciprocal. Thus, arbitrators, especially those whose careers are intertwined with the interests of the arbitration industry (in their classic 1996 study, Dezaley and Garth called these arbitrators "specialist" or "technocrat" arbitrators) ${ }^{65}$, are reasonably seen to have an interest in encouraging claims and arbitrator appointments, by interpreting the law in favour of prospective claimants. However much it may be presented as a "court", arbitration is a private business and (usually) a career path for those who are employed in the adjudication of investment disputes.

To illustrate this concern, I note the following conclusions of Dezaley and Garth, who drew on extensive interviews with arbitrators and lawyers in the field of international commercial arbitration, on the arbitration industry: ${ }^{66}$

\footnotetext{
${ }^{62} I d$.

63 This view was expressed by an arbitrator at the Harvard Law School conference, The Backlash Against Investment Arbitration (19 April, 2008). I have withheld the arbitrator's name because it was not clear at the time whether the comment was meant for attribution.

64 See, for example, Locabail v Bayfield Properties, [2000] QB 451, 471-72.

${ }^{65}$ Y. DEZALEY \& B. GARTH, DEALING IN ViRTUE: INTERNATIONAL COMMERCIAL ARbitration

\& THE CONSTRUCTION OF A TRANSNATIONAL LEgal ORDER (University of Chicago Press 1996) (hereinafter DEZALEY \& GARTH).

${ }^{66} I d$.
} 
"The operation of the market in the selection of arbitrators... provides a key to understanding the justice that emerges from the decisions of arbitrators." ${ }^{\prime 67}$

"The new generation of [arbitration] technocrats... emphasizes their ability to satisfy the consumers in order to gain repeat business." 68

"For the lawyers and their justice, the question is how to affirm the autonomy necessary for legitimacy while at the same time manifesting sufficient fidelity to the economic powers who must in the end find these services worth purchasing and deploying."

"It is good arbitration politics to thank business lawyers or other acquaintances who bring nice arbitration matters by letting them have limited access to the arbitration market. This system of exchange of favors is essential to success in arbitration, a career dependent on personal relations."70

"The growth of the market in arbitration is also evident in the competition that can be seen among different national approaches and centres., ${ }^{, 71}$

"They [the newcomer arbitrators of the 1980s and 1990s] present themselves... as international arbitration professionals, and also as entrepreneurs selling their services to business practitioners...."

"The ICC [International Chamber of Commerce] has... become one of the principal places where the "politics" of arbitration is elaborated and expressed. There are innumerable committees and multiple networks of influence that gravitate around this institution. The [ICC International Court of Arbitration], for example, which is really an oversight committee that reviews arbitration appointments and decisions, appears to be particularly sensitive to the business clientele...."

"The multinational companies are in this way investing in the construction of these legal services that serve them."

What these comments convey is that arbitrators operate in a marketplace and that this appears likely to affect how they make decisions. Arbitrators supply "symbolic capital" based on their reputations and thus have an interest to further their position and that of the industry. ${ }^{75}$ The industry is made up of cross-connected players who affiliate around

${ }^{67} I d$., at 9 .

${ }^{68} I d$. at 194.

${ }^{69} \mathrm{Id}$., at 70 .

${ }^{70} \mathrm{Id}$. at 124 .

${ }^{71} I d$., at 7 (emphasis in original).

${ }^{72} I d$. , at 36 .

$73 \mathrm{Id}$., at 45.

${ }^{74} I d$. at 93 .

${ }^{75} \mathrm{Id}$. , at $8,18$. 
prominent centres of arbitration such as the International Chamber of Commerce in Paris. Arbitrators often name each other for appointments and may exclude those who are not accepted within the industry's networks. With the passing of the old generation of gentleman arbitrators, according to Dezaley and Garth, the new technocrat arbitrators are more intent on promoting the industry in competition with its alternatives (in the present context, domestic courts and international diplomacy). ${ }^{76}$ Arbitrators, unlike judges, can earn income from activities beyond their adjudicative role. ${ }^{77}$ Prominent figures in the industry often sit as arbitrators while advising and representing claimants or respondents and while promoting arbitration clauses in investment contracts, treaties, or arbitration rules. ${ }^{78}$

This provides a basis for reasonable suspicion of bias in the investment treaty system. It raises precisely the sorts of concerns that institutional safeguards of independence dispel by removing judges from the adjudicative marketplace and positioning them instead within a public institution. It must be obvious to anyone working in the industry, as to the informed outsider, that investment arbitration cannot thrive unless international businesses consider it worthwhile to bring claims and unless powerful states also see benefits in the system. ${ }^{79}$ Arbitrators will no doubt vary in their level of commitment to values of fairness in adjudication and in their sensitivity to the "economic powers" in investment arbitration. 80 But anyone who seeks future or continued success as an arbitrator has reason to promote the system among future claimants while defending it from possible rejection by powerful states. Because this creates a credible appearance of bias in the system, and because the issues at stake involve public law, investment treaty arbitration is, in institutional terms, inconsistent with the rule of law.

The second issue, arising also from the lack of institutional safeguards of independence in the system, involves the role of the organizations that are designated as appointing authorities under investment treaties. These organizations - of which ICSID is the most prominent - exercise fundamental powers within the system. They appoint the presiding arbitrator in the absence of agreement by the disputing parties or where a party (usually the state) has declined to appoint its own arbitrator. They often play an active role in directing the negotiations between the disputing parties on who to appoint by proposing a list of prospective arbitrators which the authority would be inclined to select. And, even when the appointing authority is not active in this respect, the residual role of the appointing authority provides the backdrop for the parties' joint decision on who to appoint. Further, if a party claims a conflict of interest on the part of an arbitrator, then the claim is resolved by the appointing authority. Finally, appointing authorities may exercise key supervisory powers over the arbitration rules and over awards issued in particular cases. In the case of ICSID,

76 Id., at 50 .

77 Id., at 49-50; J.A.F. Costa, American and European Investment Arbitrators: A Single Culture?, Paper presented to Law and Society Association and the Canadian Law and Society Association conference on Placing Law, Montréal (30 May, 2008) at 7-8.

78 N. Majeed, Investor-State Disputes and International Law: From the Far Side, 98 AM. SOC'Y INT'L L. PROC. 30, 31 (2004); DEZALEY \& GARTH, supra note 65, at 8 (noting the role of repeat players, especially large law firms, in the selection of arbitration institutions and in the appointment of arbitrators).

79 W Mattli, Private Justice in a Global Economy: From Litigation to Arbitration, 55 INT'L ORG. 919, $921-22$ (2001).

80 DEZALEY \& GARTH, supra note 65 , at 70. 
awards are subject to annulment proceedings before an annulment tribunal, all three members of which are appointed by the President of the World Bank. ${ }^{81}$

The key problem here is that executive officials, however proficient and neutral they may be at an individual level, have key discretionary powers over critical steps in the adjudicative process. Institutional safeguards that would serve to address the concerns arising from this executive control of the process (i.e. safeguards such as an objective method of assignment of judges to cases and the resolution of conflict of interest against a judge by an independent adjudicative process) are absent. Thus, one may ask, for instance, whether the appointing authority is sufficiently impartial and independent and whether its power structure reflects a balance between the interests of capital-exporting and capitalimporting countries. As it stands, virtually all of the organizations that act as appointing authorities under the treaties have a decided slant in favour of the interests of capitalexporting states ${ }^{82}$ or international business. ${ }^{83}$ This supports a perception that the interests of a powerful state or a multinational firm, where implicated by the relevant dispute, have influenced the appointing authority in the exercise of its powers. Put differently, it creates a perception of bias within the system that favours the position of prospective claimants, of powerful states that hold power in the appointing authorities, and of private interests in the arbitration industry.

This structure may be an intended outcome on the part of the major states that originally designed investment treaties and thus the system. It is also presumably a desirable aspect of the present system for entities like the International Chamber of Commerce (ICC), which has pushed successfully for a regime that is highly favourable to its members and that happens also to provide new market opportunities for ICC arbitrators. Even so, such a structure is not defensible on grounds of procedural fairness and judicial independence. If the aim were to advance these values, a more obvious choice would be the use of an international body that incorporated safeguards of judicial independence to decide investorstate disputes. So long as such a body was characterized by the relevant safeguards, this would offer a credible case for the present justification of the system. Absent serious consideration of this option by major states, and considering the defensive reactions of some

${ }^{81}$ ICSID Convention, supra note 10, art. 52(3). See generally, ICSID Convention, arts. 38, 52(3), and 58; Arbitration Rules of the United Nations Commission on International Trade Law, U.N. G.A. Res. 31/98, U.N. GAOR, 31st Sess., Supp. No. 17, U.N. Doc. A/31/17, c V, s C (1976), arts. 6(2), 6(3), 7(2)-7(3), 12 (hereinafter UNCITRAL Rules); Rules of Arbitration of the International Chamber of Commerce, revised 1 January, 1998, arts. 8 and 11(3) (hereinafter ICC Rules).

82 E.g. under the ICSID Convention, supra note 10, art. 38, the President of the World Bank exercises the power to appoint. This is an official who is customarily a nominee of the U.S. Administration and who is in turn approved by other major states on the World Bank's Board of Directors. Likewise, whereas some investment treaties allocate this power instead to the Secretary General of ICSID, this is an official who is appointed by a vote of the states parties to the ICSID Convention based on a nomination by the World Bank President.

83 E.g. under investment treaties that designate the International Chamber of Commerce as appointing authority by allowing investors to bring claims under the ICC Rules. At the International Chamber of Commerce, this power is exercised by its International Court of Arbitration. Under the ICC Rules, arbitrators are appointed by the ICC's International Court of Arbitration, the members of which are chosen by the ICC world council of business on the recommendation of the ICC Executive Board. ICC Rules, supra note 81, arts. 1, 9(3)), and app I (Statute of the International Court of Arbitration of the ICC, art 3). 
in the arbitration industry to the idea, one has reason to question this justification for the system.

\section{Justification 4: Investment Treaties affirm the Sovereignty and Bargaining Strategies of States}

Investment treaties have been criticized on the grounds that many states allegedly did not appreciate the risks and obligations they were undertaking when they joined the system in the 1990s. This has been met with approbation by some advocates of the system, who say this criticism is patronizing towards developing and transition countries. One senior arbitrator, in a statement to the email listserv OGEMID ${ }^{84}$, characterized this criticism as a "shopworn and offensive canard that capital-importing countries cannot evaluate texts pressed upon them by foreigners". 85

No doubt the truth lies somewhere between the two extremes of the country that could not evaluate the treaties and the country that anticipated all their implications. That is, we may presume that states had something between zero and perfect information when they concluded the treaties that brought them into the system. It is perhaps more fruitful to ask whether states in general, especially in the 1990s, tended to have a sophisticated or unsophisticated understanding of the new regime. Examining the treaty texts and, more broadly, the political context for NAFTA, ${ }^{86}$ I tend to see more evidence for the latter position than the former. As such, I suggest here that governments in capital-importing and capital-exporting states alike may not have appreciated the consequences of the treaties and, especially, the investor-state arbitration mechanism for competing principles of legislative supremacy, governmental flexibility, and judicial independence, in particular.

\section{Did states carry out a sophisticated cost-benefit analysis?}

Let us begin with the notion that most states had a sophisticated understanding of the treaties when they entered the system. This view operates from a position of trust in the commitment and capacity of public officials to make good decisions on behalf of their people. It reflects an ideal that no government can attain perfectly, but to which all should of course aspire. Incidentally, in this respect, this view is somewhat in conflict with the assumptions that underlie justification 3 for the system regarding the reliability of domestic legal systems, as invoked by advocates of the system. But it is nonetheless laudatory to expect that public officials would not change dramatically their policies on investment and on international arbitration, via investment treaties, without careful consideration of the implications. This assumption is supported also by the decisions of many states - notably, Argentina, which has faced a flood of claims for immense sums - to maintain their treaty networks in the face of clear evidence of the risks and liabilities.

Also consistent with this perspective is the more pragmatic claim that, in concluding investment treaties, states made careful bargaining choices to relinquish their rights under

84 Oil Gas Energy Mining Infrastructure And Investment Disputes, a commercial listserve and discussion forum on international dispute management (hereinafter OGEMID). My understanding is that OGEMID operates under Chatham House rules whereby the information and opinions expressed may be cited, but based on anonymity for the source. I am tempted in the interests of open debate not to respect this rule for OGEMID, but shall err on the side of prudence.

85 OGEMID contribution of 10 April, 2007.

${ }^{86}$ J.R. MACArThur, The SELling OF “FreE Trade” (Hill and Wang 2000). 
customary international law in exchange for substantial benefits. In examining this proposition we may ask, did this bargaining choice reflect a careful weighing of costs and benefits based on a sound understanding of the treaties? In terms of the benefits, as discussed above in relation to Justification $1^{87}$, it is highly questionable to claim that states were well informed about the likelihood that investment treaties would encourage actual investment. If it is true, as much of the empirical work suggests, that the treaties have done little to attract investment, then states opted to constrain their policy options and transfer major powers to foreign investors and to arbitrators without receiving in exchange any measurable benefit in terms of actual investment. For a start, this does not seem like a good bargain.

Moreover, and quite remarkably, many of the treaties are non-reciprocal not only in effect (in that capital flows between the states parties are predominantly one-way such that the capital-importing country assumes most of the actual liabilities created by the treaty) but also in law. ${ }^{88}$ This is because the obligations assumed by the states parties under some of the treaties are explicitly unequal. In my own review of BITs over the past five years, ${ }^{89}$ I have always found that such inequality operated in favour of a major capital-exporting party and at the expense of a developing or transition state. The inequality is especially prominent in the exceptions that are incorporated by the U.S. or Canada ${ }^{90}$ to their treaty obligations to provide national treatment and most-favoured-nation (MFN) treatment, especially at the preestablishment stage. (Because of the significance of the commitment to pre-establishment national or MFN treatment, states often incorporate wide-ranging exceptions to these obligations.)

For instance, in a review of the four BITs concluded between the U.S. or Canada and an Andean Community state, it emerged that the scope and content of these exceptions were unequal. ${ }^{91}$ For example, in the U.S.-Ecuador BIT, the U.S. reserved a long list of sectors and activities from its pre-establishment obligations:

- air transportation

- banking

87 Supra. note 39,40 .

${ }^{88}$ E. Neumayer, Selfinterest, foreign need and good governance: are bilateral investment treaty programs similar to aid allocation?, at 10-11, LSE Research Online (2006), available at: http://eprints.lse.ac.uk/archive/00000808.

${ }^{89}$ Which has not been a systematic empirical review, but rather a series of periodic studies of a total of several hundred treaties selected on an eclectic basis over the course of different projects.

${ }^{90}$ European states do not commit to either national treatment or MFN treatment at the preestablishment stage in their investment treaties and so have no need to include the same exceptions.

${ }_{91}$ Treaty between the United States of America and the Republic of Ecuador concerning the Encouragement and Reciprocal Protection of Investment (Washington, 27 August, 1993; entered into force 11 May, 1997); Agreement between the Government of Canada and the Government of the Republic of Ecuador for the Promotion and Reciprocal Protection of Investments (Quito, 29 April, 1996; entered into force 6 June, 1997); Treaty between the Government of the United States and the Government of the Republic of Bolivia concerning the Encouragement and Reciprocal Protection of Investment (Santiago, 17 April, 1998; entered into force 6 June, 2001); Agreement Between Canada and the Republic of Peru for the Promotion and Protection of Investments (14 November, 2006; entered into force 20 June, 2007). 
Forthcoming: 2(1) Trade L. \& Dev. 1 (2010).

- customhouse brokers

- government grants

- government insurance and loan programs

- energy and power production

- insurance

- maritime services and maritime-related services

- $\quad$ mining on the public domain

- ocean and coastal shipping

- ownership of real property

- ownership and operation of common carrier radio and television stations

- ownership of shares in the Communications Satellite Corporation

- primary dealership in United States government securities

- provision of common carrier telephone and telegraph services

- provision of submarine cable services

- use of land and natural resources

By comparison, Ecuador reserved very few sectors and activities:

- $\quad$ traditional fishing (not including fish processing or aquaculture)

- ownership and operation of broadcast radio and television stations

Thus, the U.S.-Ecuador BIT is unequal in terms of the scope of pre-establishment obligations that are assumed by the states parties. The U.S. has reserved for itself the right to maintain foreign admission and ownership restrictions, thus allowing it to maintain national control of strategic sectors and to preference domestic capital. U.S. banks, for example, are protected from competition in their home markets from Ecuadorian banks, but have the right to establish themselves and compete in Ecuador. ${ }^{92}$ Ecuador, on the other hand, has

\footnotetext{
${ }^{92}$ Of course, it is unlikely that Ecuador would have a sufficient base of capital to generate domestic investors that could in turn acquire ownership and control in strategic sectors in the U.S. That said, by forum-shopping, a holding company in Ecuador could be used as a vehicle for foreign capital from elsewhere to enter the U.S. economy.
} 
relinquished its right to limit and screen foreign investment such that it must open its economy to foreign entry and ownership.

This inequality under investment treaties is present, to varying degrees, in all four BITs concluded by the U.S. or Canada with an Andean Community country. ${ }^{93}$ In each case, the developing state is given much less policy space to screen or condition foreign investment or to preference domestic firms. ${ }^{94}$ This is counter-intuitive from a development perspective, in that major capital-exporting states have reserved the ability to protect their economies and pursue a national industrial policy while their developing country counterpart, presumably without a strong base of domestic firms that can compete at the international level, must allow foreign capital to flood virtually all sectors of the local economy.

Of course, states might have decided to conclude investment treaties - however unequal in fact or in law - because they perceived other benefits of doing so (or other risks of not doing so). For one, as discussed, they may have believed it self-evident that the treaties would increase actual investment flows from the opposite state party. Or they may have wished to avoid punitive responses or recriminations by powerful states. Put differently, we might simply acknowledge that the bargaining choices of states are made in a political context that goes beyond consideration of markets and the movement of capital flows or in themselves. At a certain point, though, the treaties become less a bargain and more simply a capitulation by the weak to the powerful, without material consideration in exchange for an offer to open the host economy to foreign ownership. ${ }^{95}$ The treaties, that is, offer evidence that undermines the present justification of the system. Just as the unequal treaties of earlier periods were condemned on normative grounds, ${ }^{96}$ so too can investment treaties be criticized for a lack of reciprocity in the benefits they bestow.

\section{Did developing and transition states appreciate the risks?}

This leads to the related question of whether states that have entered into investment treaties fully appreciated the risks of those treaties when they were concluded. Let us begin with developing and transition states. Does it appear that they committed the necessary resources and expertise in their governments to analyze the treaties in order to make careful decisions to conclude them? We have indications that they did not. There are reports of investment treaties being signed as photo opportunities at road shows by public officials. ${ }^{97}$ Pakistan's former Attorney General, Makhdoom Ali Khan, has reported that there was little evidence in the early 2000s, when his country faced its first BIT claim, that ministries in the Pakistani government (beyond the one that had signed them) were aware of the country's BITs and

\footnotetext{
93 Supra note 91.

${ }^{94} \mathrm{On}$ the other hand, even in the case of the U.S. and Canada, significant gaps are apparent where sectoral exceptions included in one BIT are omitted from another BIT, particularly where the latter allows forum-shopping.

${ }^{95}$ Republic of South Africa, supra note 55.

${ }^{6}$ M.R. Auslin, Negotiating with Imperialism: The Unequal Treaties and the Culture OF JAPANESE Diplomacy (Harvard University Press 2004); D. WANG, ChInA's UneQUAL TREATIES: NARRATING NATIONAL HisTORY (Lexington Books 2005).

${ }_{97}$ See, for example, L. Poulsen and D. Vis-Dunbar, Reflections on Pakistan's investment-treaty program after 50 years; an interview with the former Attorney General of Pakistan, Makbdoom Ali Khan, INVESTMENT TREATY NEWs (16 March, 2009) (hereinafter Poulsen \& Vis-Dunbar).
} 
that he was unable to uncover any records demonstrating meaningful participation by Pakistan in the BIT negotiations. ${ }^{98}$ Since his term as Attorney General ended in 2007, he reported, Pakistan has continued to conclude BITs without analysis of the risks and without proper government resourcing.

Similarly, a South African government commission reported recently that: ${ }^{99}$

"Prior to 1994, the RSA [Republic of South Africa] had no history of negotiating BITs and the risks posed by such treaties were not fully appreciated at that time. The Executive had not been fully apprised of all the possible consequences of BITs. While it was understood that the democratically elected government of the time had to demonstrate that the RSA was an investment friendly destination, the impact of BITs on future policies was not critically evaluated. As a result the Executive entered into agreements that were heavily stacked in favour of investors without the necessary safeguards to preserve flexibility in a number of critical policy areas. In reviewing the travaux preparatoires of the various BITs entered into at the time, it became apparent that the inexperience of negotiators at that time and the lack of knowledge about investment law in general resulted in agreements that were not in the long term interest of the RSA."

These are serious, indeed extraordinary, admissions for a government to make. Of course, two examples do not make a pattern. On the other hand, if we expect that officials and governments generally prefer not to admit mistakes - specifically that they were not well informed when they made an important and long-lasting policy decision - then it is reasonable to conclude that others were in a similar situation to that of Pakistan and South Africa at the operative periods. ${ }^{100}$

3. The role of key actors in promoting the system

Besides the role of states themselves, further study is warranted on the role played by actors in the arbitration industry in the promotion of the system. There are a number of prominent individuals who work as counsel or as arbitrators in the system, who appear to have had a role in the negotiation of the treaties, and who are strong advocates for the system. Typically they are based in large international law firms although they may move in and out of government positions as well. Two persons who appear to have played a role in this respect are Jan Paulsson and Daniel M. Price.

Paulsson is a prominent figure in arbitration, especially in Europe. As of December 2009 he was co-head of the arbitration and public international law departments at Freshfields LLP in Paris. ${ }^{101} \mathrm{He}$ was also president of the London Court of International

\footnotetext{
${ }^{98} I d$.

${ }^{99}$ Republic of South Africa, supra note 55.

100 One story relayed to me by a prominent counsel and arbitrator was that, when representing a developing state in response to the first investment treaty claim against it, he learned that the country in question, when it received the claim, was unable to find a copy of the treaty and so had to ask for one from the counsel for the claimants. That a government would have to resort to this embarrassing step suggests that it lacked even a basic awareness of the risks associated with the investment treaty regime.

${ }^{101}$ Freshfields, People: Jan Paulsson, available at: www.freshfields.com/people/profile/11/2654.
} 
Arbitration and the World Bank Administrative Tribunal. In 1996, Dezaley and Garth described Paulsson as "one of the leading Paris members of the new generation" of professional arbitration specialists and as having "excellent connections to the major institutions and journals, a strong base in practice as arbitrator and lawyer, and the capital that comes from major publications". ${ }^{102}$ Paulsson holds several academics titles, including chairs at the Universities of Dundee and Miami and a visiting professorship at the London School of Economics and Political Science. He got his start in international arbitration in 1975 as a new associate at the New York-based law firm Coudert Brothers, working on one of the Libyan oil nationalization cases. ${ }^{103}$

Paulsson is a prominent actor in the field of commercial and investment arbitration. He has served as counsel or as an arbitrator in at least 13 investment arbitrations, including six as the presiding arbitrator, six as the investor-appointed arbitrator, and one as the stateappointed arbitrator. ${ }^{104}$ In the early 1990s, Paulsson advised Mexico on the negotiation of NAFTA Chapter 11 and he has taken responsibility for conceiving and drafting its mechanism on the consolidation of investor claims (NAFTA Article 1126). ${ }^{105} \mathrm{He}$ has not moved in and out of government positions although he does appear on behalf of government at official meetings, as when he reportedly represented first the London Court of International Arbitration and then Bahrain in recent UNCITRAL meetings on the revision of its arbitration rules. ${ }^{106}$ Paulsson is also one of Bahrain's appointees to the ICSID Panel of Arbitrators. ${ }^{107}$

An element of Paulsson's prominence in the industry is his strong promotion of the investment treaty system. I shall review, in some detail, some of the advocacy positions that he has adopted in this respect, both in arbitration awards and in published statements. These are intended as examples and I do not claim to provide a fulsome sample in this respect. I should also note that Paulsson, as an arbitrator, has been party to decisions that were decided against the investor interest and in favour of states. ${ }^{108}$ Based on the available record of awards by tribunals on which he has sat, Paulsson does not appear to be a strongly proinvestor (or pro-state) arbitrator relative to others who are appointed frequently under investment treaties. That said, Paulsson has participated in tribunals that interpreted investment treaties in ways that significantly expanded the scope of the system and its compensatory promise for investors.

For instance, Paulsson was the presiding arbitrator on the GAMI tribunal, which took the unusual step of rejecting the submissions of both the investor's home state (the U.S.) and the host state (Mexico) in that case on how to resolve an issue of NAFTA

102 DEZALEY \& GARTH, supra note 65, at 140 and 24, respectively.

103 Id., at 24.

104 This is based on my own collected data which is limited due to its reliance on publicly reported information and the continuing confidentiality in many investment arbitration cases on key facts, such as who has been appointed to the tribunal or even fact that a claim exists. See also supra note 22.

105 J. Paulsson, Arbitration Without Privity, 10 ICSID Rev.-Foreign Investment L.J. 232, 248 (1995) (hereinafter Paulsson-Arbitration Without Privity).

106 Email to the Author from an individual who attended the relevant UNCITRAL meetings, dated 28 December, 2009.

107 ICSID, Members of the Panels of Conciliators and of Arbitrators (October 2009) at 11.

108 See, for example, Azinian (Robert) et al v United Mexican States (1 November, 1999), 14 ICSID REV. 538, 39 I.L.M. 537, 5 ICSID REP. 272, 19 83, 87. 
interpretation involving claims by minority shareholders. ${ }^{109}$ Both the U.S. and Mexico submitted that a NAFTA claim by a U.S. company that was a minority shareholder in a Mexican company - which had allegedly been expropriated by Mexico - could be advanced under NAFTA only in relation to injuries to the minority shareholder itself and not for injuries to the domestic company. This was an important distinction to draw because allowing a minority shareholder to step into the shoes of a domestic company would facilitate parallel claims under NAFTA and domestic law and thus expand opportunities for gaming by investors of the NAFTA arbitration mechanism. The GAMI tribunal, on which Paulsson was the presiding arbitrator, rejected these submissions of the two states parties, in favour of those of the investor, thus expanding significantly the jurisdiction of arbitrators under NAFTA Chapter 11.

In his published work as well, Paulsson has advocated for interpretations of investment treaties that favoured claimants and has criticized others that limited the risks of the system for states (although Paulsson has also cautioned arbitrators not to go too far in favour of investors lest states "take fright" and withdraw from the system ${ }^{110}$ ). For example, Paulsson commented that he found it "astonishing" that the Loewen tribunal - in the face of silence on the point in NAFTA - would decide that the duty to exhaust local remedies was not removed by NAFTA in the case of a claim that the U.S. violated NAFTA's minimum standard of treatment following a decision of one of its domestic courts. ${ }^{111}$ In Paulsson's words, this was tantamount to reading a requirement to exhaust local remedies "as an implied condition" of investor claims under NAFTA. ${ }^{112}$ To be clear, Paulsson's position on this point is not without foundation, given the ambiguity of the NAFTA text. The point here is simply that Paulsson saw fit to criticize openly another NAFTA tribunal and to favour, from a position of prominence in the arbitration industry, the resolution of the issue in favour of claimants and in favour of an expansive approach to the system.

Paulsson has also spoken strongly against those who criticize the use of investment treaty arbitration on grounds that it restricts democratic choice, unduly dismisses the role of the domestic legal system, or undermines important values such as judicial independence. For instance, in his book, Paulsson lambasted critics in the U.S. Congress, media, and nongovernmental organizations who criticized NAFTA Chapter 11 and the power it gives to large companies and to arbitrators. Paulsson commented: ${ }^{113}$

"The neonationalist currents seem most persuasive to those who are attracted by sensationalist allegations of conspiracies against the public interest, and are disinclined to make an effort to grasp the more complex themes of international rules and economic cooperation. The shrill voices will always be with us. They are an inevitable part of democratic debate. It would be our loss if they fell silent; they provide valuable occasions to articulate rational rebuttals of the extreme positions which underlie appeals to public prejudice."

109 GAMI Investments, Inc v Government of the United Mexican States (15 November, 2004), 44 I.L.M. 545, 17(2) WORLD TRADE \& ARB. MATERIALS 127.

110 Paulsson-Arbitration Without Privity, supra note 105, at 257.

111 Paulsson-Arbitration Without Privity, supra note 105, at 240.

${ }_{112} I d$.

113 PAULSSON, supra note 3, at 231-2. 
This was an aggressive advocacy position in defence of investment treaty arbitration. While calling for rational rebuttal of the system's critics, Paulsson's own response to critics of NAFTA Chapter 11 (over the course of two pages in the book) was to refer to them "shrill", "neonationalist", sensationalist, attracted to "conspiracies", lacking in "political maturity", "true believers", "[s]ervants of their revelation", and propagandists "who care little about the means of advancing their cause". ${ }^{114}$ To be fair, Paulsson also laid out various reasoned replies. But it is indicative of his advocacy for the system that he adopted such strong language in responding to criticisms of investor-state arbitration under NAFTA Chapter 11.

Another prominent advocate for investment arbitration whose role I will outline briefly is Daniel M. Price. Price is a Washington-based lawyer and arbitrator who has held official positions in the U.S. government. As of December 2009, Price was senior partner for global issues at Sidney Austin LLP, an international law firm, where he "represents clients on a range of international regulatory, transactional and policy matters" while also representing clients "in the resolution of international disputes". ${ }^{115}$ In the Administration of George W. Bush, Price held the positions of Assistant to the President and Deputy National Security Advisor for International Economic Affairs, where he was the senior White House official responsible for international economic issues, including international investment. He was President Bush's personal representative to the G-8, G-20 Financial Summit, and APEC Forum. Earlier in his career, Price was the U.S. Trade Representative's lead negotiator on investment in the NAFTA negotiations and was a legal advisor on negotiations toward a Uruguay Round investment agreement. During 1989-2002, he was Principal Deputy General Counsel of the U.S. Trade Representative, where he negotiated investment treaties with Eastern European and Latin American states. He appears to have gotten his start in the general field of investment arbitration in 1984-86, when he represented the U.S. government and advised U.S. businesses in arbitrations before the Iran-U.S. Claims Tribunal. More recently, Price served as counsel to investors in investment arbitrations against Argentina, India, Mexico, Pakistan and Poland, and as counsel to the governments of Turkey and Peru in such arbitrations. ${ }^{116}$

Price also works as an arbitrator in the system. He was (or is) an arbitrator in at least five cases under investment treaties. It is probable in light of his background that Price was appointed in all of these cases by the claimant (investor), although this cannot be verified in all cases due to the lack of openness in UNCITRAL arbitrations involving the Permanent Court of Arbitration. ${ }^{117}$ Because ICSID arbitrations are more open, however, we know that Price was the investor's appointee to the Tokios tribunal, which produced a highly proinvestor jurisdictional decision that allowed a group of Ukrainians to bring a claim against their own government (under the Ukraine-Lithuania BIT) by way of a holding company in Lithuania. ${ }^{118}$ (In opposition to this pro-investor interpretation, the presiding arbitrator on the tribunal, Prosper Weil, dissented and then resigned from the tribunal.) The decision of the majority of the Tokios tribunal remains controversial because of the extent to which it

${ }^{114} I d$., at 232-3.

115 Sidney Austin, Our People: Daniel M. Price, available at: www.sidley.com/ourpeople/detail.aspx?FullBio=true\&attorney $=357$.

${ }^{116} I d$.

117 In both cases where the information is publicly available, Tokios, supra note 38, and Saluka Investments BV (The Netherlands) v. The Czech Republic, UNCITRAL, (Sep. 7, 2006), Price was appointed by the claimant.

118 Tokios, supra note 38. 
expanded the scope of the system in the face of ambiguity in the relevant BIT and the ICSID Convention.

Of course, actors like Price and Paulsson are not themselves responsible for the system; it is governments that concluded the treaties. But, to understand the decision-making of states, an inquiry is also warranted into how actors in the arbitration industry may have affected the conclusion as well as the interpretation of investment treaties. The same goes for organizations beyond national governments that have encouraged the conclusion of investment treaties. Not surprisingly, business organizations have championed the system in its muscular form and have reacted defensively to proposals for reform. ${ }^{119}$ It is also notable that the Paris-based International Chamber of Commerce was given the role of appointing authority mainly in investment treaties of Western European (and not North American) capital-exporters. Considering that the ICC is itself a business organization, it is important to take into account its role both as advocate for the system on behalf of business and supplier of arbitration services, on the one hand, and as an official appointing authority under investment treaties, on the other. Finally, international organizations - such as UNCTAD's Division on Investment, Technology, and Enterprise Development through its work programme on investment treaties ${ }^{120}$ - have played an important role in promoting and facilitating the conclusion of investment treaties. ${ }^{121}$ From the late 1990s, UNCTAD has organized "capacity-building seminars, regional symposia, training courses, dialogues between negotiators and groups of civil society on the subject". ${ }^{122}$ Investment treaties were also reportedly signed en masse at UNCTAD meetings organized for developing states. ${ }^{123}$ Since the late 1990s, UNCTAD has published an extensive working paper series that tended to neglect or under-state the risk of investor claims and the implications for policy space. ${ }^{124}$

119 Most recently, in the review of the U.S. Model Bilateral Investment Treaty: U.S. Advisory Committee on International Economic Policy, Report of the Advisory Committee on International Economic Policy Regarding the Model Bilateral Investment Treaty Presented to: The Department of State 30 September, 2009), Annex B, 18-27 and 30-1.

120 P.T. Muchlinski, Attempts to Extend the Accountability of Transnational Corporations: The Role of UNCTAD, in LIABILITY OF MULTINATIONAL CORPORATIONS UNDER INTERNATIONAL LAW 97105 (M. T. Kamminga \& S. Zia-Zarifi eds., Kluwer Law International 2000)(hereinafter Muchlinski).

121 Besides UNCTAD's numerous publications on the topic, see e.g. World Bank, World Development Report 2005 - A Better Investment Climate for Everyone (New York: IBRD/ Oxford University Press 2004), which discusses the role of investment treaties in reducing barriers to international investment and in contributing to investment climate improvements without mentioning the risks posed by investment treaty arbitration to states.

122 R. Ricupero, "Preface" [dated December 1998] in UNCTAD, "Admission and Establishment", UNCTAD Series on issues in international investment agreements (2002). Muchlinski, supra note 123 , at 113 .

${ }^{123}$ Elkins, Guzman \& Simmons, supra note 28, at 818-19.

${ }^{124}$ I was informed by a former UN official that the UNCTAD's Division on Investment, Technology and Enterprise Development held views on FDI that were "in marked contrast to the rest of UNCTAD". Email to the author (6 December, 2009). On the closing of space for development policies, see UN Development Programme, Human Development Report 2005 (New York: UNDP, 2005), at 133-9. 
4. Did capital-exporting states appreciate the risks?

What about the major capital-exporting states? To what extent did they understand the risks as well as the benefits of the expansion of their treaty networks? One may assume that there were at least groups of officials in Western Europe and North America (where the treaties were devised from the 1960s through the 1980s) who understood clearly what they were negotiating. Officials in the UK, for example, must have had a sophisticated understanding of most-favoured-nation (MFN) treatment when they incorporated express language into some UK BITs ${ }^{125}$ that extended MFN treatment from substantive to procedural aspects of other BITs, given that this language anticipated the complex questions of interpretation that were famously resolved in favour of claimants in Mafferini ${ }^{126}$ and (especially) Siemens. ${ }^{127}$ We may also assume that UK officials realized the significance of provisions in the UK-Egypt BIT that allow for forum-shopping by investors against Egypt but that shield the UK from reciprocal forum-shopping by requiring Egyptian investors to have their corporate seat in Egypt. ${ }^{128}$ In both respects, UK officials were capable of careful refinement of their treaties to enhance the protection of UK investors or to insulate the UK from certain types of claims (although neither of these provisions, especially the latter, is reflected in all of the UK's BITs). On the other hand, it may be that a sophisticated understanding on the part of some officials in the UK or the other capital-exporting states that negotiated the treaties was not shared by officials elsewhere in government, especially those responsible for the regulatory activities that impact on investors.

If any governments understood the risks posed by investment treaties to policy space and to principles of democratic choice or judicial independence, one may assume it was the governments of major states which have the expertise and resources to conduct careful analysis when designing and negotiating their treaties. In the case of NAFTA, this assumption is open to question. The experience of NAFTA Chapter 11 from the mid-1990s, when companies began to bring claims against the U.S. and Canada, indicated that key decision-makers in those countries had little understanding of the implications of investorstate arbitration or of the important powers it assigned to arbitrators. ${ }^{129}$ After seeing the arbitration mechanism in operation, the NAFTA states took the significant step - in the face

${ }^{125}$ E.g. Agreement between the Government of the United Kingdom of Great Britain and Northern Ireland and the Government of Barbados for the Promotion and Protection of Investments with Protocol (Bridgetown, 7 April, 1993; U.K.T.S. No. 54 (1993); entered into force 7 April. 1993), art. 3(3) (hereinafter the UKBarbados BIT); Agreement between the Government of the United Kingdom of Great Britain and Northern Ireland and the Government of the Republic of Chile for the Promotion and Protection of Investments with Protocol (Santiago, 8 January, 1996; U,K,T,S, No, 37 (1997); entered into force 21 April, 1997), art. 3(4) (hereinafter the UK-Chile BIT).

126 Maffezini (Emilio Agustín) v. Kingdom of Spain (25 January, 2000), 16 ICSID REV. 212, 124 ILR 9.

127 Siemens AG v Argentine Republic (3 August, 2004), 44 I.L.M. 138.

128 Agreement between the Government of the United Kingdom of Great Britain and Northern Ireland and the Government of the Arab Republic of Egypt for the Promotion and Protection of Investments (London, 11 June, 1975; U.K.T.S. No. 97 (1976); entered into force 24 February, 1976), art. 1(d)(ii) (hereinafter the UK-Egypt BIT).

${ }^{129}$ Former U.S. Congressman Abner Mikva and a member of the Loewen tribunal under NAFTA said of NAFTA investor-state arbitration: "If Congress had known that there was anything like this in NAFTA, they would never have voted for it". A. Liptak, Nafta Tribunals Stir U.S. Worries, N.Y. TIMES, 18 April, 2004. 
of opposition by many in the arbitration industry ${ }^{130}$ - of requiring openness in the arbitration process and of clipping the discretion of Chapter 11 arbitrators after tribunals had interpreted NAFTA in ways that went well beyond the submissions of the NAFTA states. (It remains to be seen whether a similar reaction will emerge in the major Western European capital-exporters if and when their governments become the subject of substantial investor claims. ${ }^{131}$ ) If the U.S. and Canada were caught off guard by aspects of NAFTA Chapter 11 arbitration, ${ }^{132}$ where it was included as part of a trade agreement that was debated extensively in both countries, ${ }^{133}$ then how likely is it that governments with fewer resources were able to develop a sophisticated understanding of the risks of investment treaties that received little or no public attention when they were concluded? ${ }^{134}$

For these reasons, on balance there is reason to doubt that governments, beyond the groups of officials who negotiated the treaties, tested the anticipated benefits of the treaties, appreciated the risks of investor-state arbitration, and carried out sophisticated cost-benefit analyses of their commitments to compulsory international arbitration before committing themselves to the treaty system. This is significant if one considers the degree to which the system marks a major transformation of longstanding policies of governments on the national and international legal framework for self-determination. Undoubtedly, more systematic empirical work would be required to reach confident conclusions on the historical situation of particular countries and particular treaties. Even so, there is significant evidence against the claim that the investment treaty system reflects a process of informed sovereign consent and thoughtful strategy on the part of states.

\section{E. Justification 5: Investment Treaties were Endorsed by the Democratic Process}

In some respects, the fifth justification for the system is a softer version of the claim that states were well-informed when they concluded their key investment treaties. It is softer in that it asserts that, even if top-level decision-makers in national executives and legislatures were not well-informed about the consequences of the treaties and of their consents to investment arbitration, the decisions to conclude the treaties was nevertheless understood to be consistent with a wider neo-liberal policy ${ }^{135}$ of the state and of the electorate. The objective was to withdraw government from the economy and to open the economy to foreign capital; investment treaties were a tool to do so. ${ }^{136}$ Elections were held and duly elected governments concluded the treaties. Opportunities were afforded for debate; dissenting views were voiced and heard. In the end, the relevant entities of the state choose

130 See, for example, T. Weiler, NAFTA Investment Arbitration and the Growth of International Economic Law, 36 CAN. Bus. L.J. 405, 422-30 (2002); C.N. Brower, C.H. Brower II \& J.K. Sharpe, The Coming Crisis in the Global Adjudication System, 19 ARB. INT'L 415, 434-35 (2003).

131 See the recent claim against Germany by a Swedish energy company in response to environmental restrictions on a coal-fired power plant in Hamburg. S. Knauer, Vattenfall vs. Germany: Power Plant Battle Goes to International Arbitration, Spiegel Online (15 July, 2009), available at: www.spiegel.de/international/ germany/0,1518,druck-636334,00.html.

132 Brower \& Steven, supra note 60, at 194-5; Laird, supra note 60, at 224-5.

133 PAULSSON, supra note 3, at 237-8.

134 Poulsen \& Vis-Dunbar, supra note 97.

135 SCHNEIDERMAN, supra note 18, at 2.

136 The role of BITs in the privatization program adopted in Argentina in the early 1990s is a good example. Collinson, supra note 29, at 13. 
to reform their economies and, as a component of this, to join the international investment regime. Whether governments foresaw all of the consequences is not the test; the test is whether they consented according to the requirements of domestic law. Normatively, the treaties capture an ideological spirit of a time. Formally, they were signed and ratified and should be respected. ${ }^{137}$

This line of argument is central to the regime as both a legal construct and a normative project. It is central to the legal construction of the regime in that the lawyers and arbitrators who wield power in the system derive their authority from the treaties. States used the treaties to subject themselves to rigorous standards that protect investors and to refer investment disputes to arbitration. The treaties must be interpreted and applied in light of this purpose as well as their text and context. As a matter of positive law, this is fundamental. ${ }^{138}$

The weakness of this construction, however, is that the law is often silent or ambiguous on key matters of its meaning. These matters are left to resolution by the adjudicative process. ${ }^{139}$ In the case of investment treaties, there is much uncertainty about the meaning of many of the obligations that states assumed. Investment treaties refer to core concepts at a high level of generality. The treaties are also not as easily revised by their authors as in the case of domestic legislation. ${ }^{140}$ In turn, the treaties give arbitrators a central law-making role in the exercise of their discretion about what the system should do, and the decisions of the arbitrators are not subject to fulsome review in an independent court, whether domestic or international. It is only part of the story, then, for Paulsson to claim that "Arbitral tribunals are not to be blamed for the contents of treaties". ${ }^{141}$

Arbitrators must therefore often defend their interpretive decisions not simply on the basis that "this is what the treaty says" but rather, "the treaty does not answer this question, but we decided in favour of option A rather than option B". In many awards to date, "option A" has been an interpretation of a treaty that was expansive of the protections offered to investors and of the system's compensatory promise for international business. As mentioned above, such interpretations have been adopted in some cases by tribunals even where the states party to the treaty (including the investor's home state) agreed that the treaty called for a more restrictive interpretation.

Beyond the legal construction of the system, moreover, there is a basic problem with the claim that investments treaties reflect the democratic choices of states. This is the problem that the terms of most of the treaties show little respect for democratic choice. First, the treaties do not contain even a narrow exception for legislative decisions, subjecting these decisions rather to the full force of the treaty even when a legislature makes a decision of a general nature, when it responds to a major emergency in the country, or when its decision is supported by an overwhelming majority of the country's elected representatives. The lack of a broad exception for general legislative measures raises doubts about the claim of harmony between investment treaties and democracy.

\footnotetext{
137 Brower \& Steven, supra note 60, at 195.

138 An example is provided by PAULSSON, supra note 3, at 263: "Criticism of international tribunals on the grounds that they impede democratic policies... is misdirected. International tribunals do not establish policy. They give effect to international agreements....".

139 PAULSSON, Id., at 252; Brower \& Steven, supra note 60, at 199-200.

140 Choudhury, supra note 18, at 788-9.

141 PAULSSON, supra note 3, at 265.
} 
In addition, investment treaties usually put time limits on the right of the states parties to withdraw from the treaties. That is, they do not allow future decision-makers, also duly elected, to revisit the state's decision to commit to the system. It is true that some of the treaties allow for their cancellation by a state party on short notice - such as 6 months in the case of NAFTA - but most give far less opportunity for democratic reconsideration of the state's decision. Typically, BITs apply for an initial period of 10 to 15 years and then roll over for another 10 to 15 year period. At the time of roll over, there is often only a short period (usually 6 months to a year) in which a state may exercise its right to withdraw from the treaty. Thus, many of the treaties operate like inflexible term deposits: they require the state to lock up its policies for a lengthy period with only occasional windows of opportunity to cancel the term.

Moreover, virtually all investment treaties maintain the obligations of the states parties for an extended period for foreign investors whose investments existed at the time the treaty was cancelled. One may of course justify such provisions on the basis that, if the treaties are to attract foreign investment, they must cover a period sufficient to provide security to the relevant investors. But, as discussed above, there are reasons to doubt whether the treaties actually serve this end. As such, there is a strong case for the use of other means, especially the conclusion of investment contracts, for a state to tailor their approach to foreign investment according to its wider development strategy. ${ }^{142}$

For these reasons, it is questionable whether the investment treaty system respects the basic principle that one elected government may not bind another in a way that fundamentally restricts the policy options of the latter. ${ }^{143}$ In common law, this principle is referred to as the no-fettering rule and it is an important component of legislative supremacy. ${ }^{144}$ In light of this principle, those who argue that investment treaties respect democratic decisions must explain why the rights and privileges of investors should be locked in for generations, while the electorate as a whole - if it rejects the investment treaty system after learning how it operates - is required not only to elect a new government but to do so at particular periods of time when the country's treaties are up for renewal. Even then, the electorate's decision is subject to a lengthy time lag during which the treaty limitations on government decision-making continue to apply. It is dubious to justify as democratic a decision to constrain electorates in this way.

\section{CONCLUSIONS}

I have examined five justifications for an investment treaty system that has been in ascendance since the 1990s. The discussion focused on the position of states and other actors that make decisions about the system's costs and benefits and about the values that are said to underlie it. The analysis suggests that governments should exercise greater care when considering entry into the system or, more likely, the renewal or expansion of existing treaty networks, and calls for thorough examination of the options for reform.

The focus has been on "muscular" components of investment treaties; most states have subjected themselves to a treaty that contains most or all of these components. These components have also prompted the bulk of the concern about the system as a whole.

${ }_{142}$ J.W. Yackee, Do We Really Need BITs? Toward a Return to Contract in International Investment Law, 3 ASIAN J. WTO \& INT’L HEALTH L. \& POL'Y 121 (2008).

143 SCHNEIDERMAN, supra note 18, at 189.

144 A.C.L. Davies, Ultra Vires Problems in Government Contracts, 122 L. Q. REV. 98, 104-5 (2006). 
Despite this, the major capital-exporting states have shown little interest in fundamental reform. To the extent that this stems from justifications that were examined here, it is problematic. To the extent that it reflects other justifications, such as the definition by major states of their national interest as coincidental with the interests of international businesses, the system should be debated on such terms so that governments and electorates can respond in an informed way. Thus far, the major states' disinterest in fundamental reform suggests that serious alternatives to the system are more likely to emerge on a bilateral or regional basis, much as the system was grown over time, and that they will evolve in contrast to a mainstream of investment arbitration that is staunchly resistant to change.

At a normative level, the widespread claims that investment treaty arbitration was designed to address inadequacies of domestic legal systems, and to advance the rule of law through the use of international adjudication, are undermined by the design of the treaties and by the lack of fairness and independence in the arbitration mechanism. Because they lack institutional safeguards of independence, investment arbitrators are vulnerable to inappropriate influence by private actors that have clout in the arbitration industry and by the states or business entities that dominate voting and appoint officials in key appointing authorities. The appointing authorities are central to the system because they have the power to decide the make-up of the tribunals, the content of the arbitration rules, and the conduct of the process by which awards are reviewed.

In the history of investment treaties, developing and transition states were presented with take-it-or-leave-it offers from major capital-exporters to conclude investment treaties that, it was said, would attract foreign investment in exchange for commitments by capitalimporting countries not to expropriate or discriminate against foreign investors. There is now much evidence that the promised benefit did not materialise, whereas the obligations of host states have emerged as wide-ranging constraints on general regulations adopted in good faith and on a non-discriminatory basis. Many states have faced the challenge of unexpected waves of claims against them on matters of economic development, financial security, environmental and health regulation, and so on. If reform is to come, it is likely to originate in these countries. ${ }^{145}$

One avenue for reform lies in the renegotiation or abrogation of investment treaties. Another lies in reform of the institutional mechanisms and, specifically, in the creation of alternative forums and processes for the resolution of investment disputes. It would be beneficial to their perceived neutrality if such alternatives were based outside of the conventional arbitration centres of Western Europe and North America and if they surpassed the current system in terms of their incorporation of institutional safeguards of judicial independence. However, while all states should strive for a system that is consistent with values of fairness independence in adjudication, it is just as critical for developing and transition countries to formulate appropriate strategies on the investment treaty system after careful assessment of its costs and benefits alongside those of the alternatives. ${ }^{146}$

145 Salacuse, supra note 36, at 251.

146 A model is that of the Republic of South Africa, supra note 55. See also Mortimore \& Stanley, supra note 25 , at $33-45,51-5$. 